\title{
SURFACE PROFILES OF THE LAURENTIDE ICE SHEET IN ITS MARGINAL AREAS
}

\author{
By W. H. Mathews \\ (Department of Geological Sciences, University of British Columbia, Vancouver 8, \\ British Columbia, Canada)
}

Abstract. Surface slopes of ice lobes can be estimated from the gradients of their margins as shown by ice limits, by contemporaneous recessional moraines, or by lateral melt-water channels, with allowance being made for the dip of an ice lobe laterally, as well as forward, toward its extremities. Profiles can be fitted approximately to a parabola with the equation

$$
h=A x^{i}
$$

in which $h$ is the height above and $x$ the distance up-stream from thè terminus, in the same units, and $A$ is a coefficient which varies from glacier to glacier. The coefficient $A$ has a value of $4.7 \mathrm{~m}$ for both the Antarctic ice sheet inland from Mirny and the west central Greenland ice sheet. Several examples of late Pleistocene ice lobes within mountainous terrain of North America and New Zealand have values of $A$ ranging from $2.9 \mathrm{~m}^{\mathrm{t}}$ to about $4.1 \mathrm{~m}^{\mathrm{t}}$. For several ice lobes in the south-western part of the late Pleistocene Laurentide ice sheet, however, values are from about 0.3 to $1.0 \mathrm{~m}^{\mathbf{t}}$, corresponding to basal shear stress of from about 0.07 to 0.22 bar. A major problem exists in accounting for the active movement of ice here under such low surface gradients and basal shear stresses. Evidence of basal slip, aided by high subglacial water pressure, should be looked for in the field. Alternatively, other possibilities for the explanation of such low surface gradients should be sought.

RÉsumé. Profils superficiels de la calotte glaciaire de Laurentide dans ses zones bordières. La pente de la surface des lobes glaciaires peut être estimée à partir des étagements de leurs fronts que montrent les limites de la glace, par les moraines de recession contemporaines, ou par les chenaux latéraux d'écoulement d'eau de fonte, en tenant compte du plongement d'un lobe de glace latéralement comme en avant vers ses extrémités. Les profils peuvent être représentés approximativement par une parabole d'équation:

$$
h=A x^{\mathbf{t}}
$$

dans laquelle $h$ est la hauteur au dessus du front, $x$ la distance à ce front, toutes deux exprimées dans les mêmes unités, et $A$ un coefficient qui varie d'un glacier à l'autre. Le coefficient $A$ a la valeur de $4,7 \mathrm{~m}^{\mathbf{t}} \mathrm{a}$ la fois pour la calotte antarctique à la hauteur de Mirny et la partie centrale occidentale de la calotte Groenlandaise. Plusieurs exemples de lobes de glace du Pleïstocène récent dans les régions montagneuses d'Amérique du Nord et de Nouvelle-Zélande ont des valeurs de $A$ entre $2.9 \mathrm{~m}^{\mathbf{t}}$ et environ $4.1 \mathrm{~m}^{\mathbf{t}}$. Pour plusieurs langues de glace dans la partie sud-ouest de la calotte glaciaire de Laurentide au Pleïstocène récent, les valeurs de $A$ sont cependant de 0,3 à $1,0 \mathrm{~m}^{\mathbf{l}}$, correspondant à une contrainte de cisaillement à la base allant d'environ 0,07 à 0,22 bar. Un problème plus grand est posé pour rendre compte du mouvement actif de la glace sous des gradients de surface et des efforts de cisaillement à la base aussi bas. Les traces de glissement à la base, aidé par les hautes pressions des eaux sous-glaciaires devraient être recherchées sur le terrain. Sinon, d'autres possibilités devraient être imaginées pour expliquer de si faibles gradients de pente en surface.

Zusammenfassung. Oberflächenprofile des Laurentidischen Eisschildes in seinen Randgebieten. Oberflächenneigungen von Eis-Loben lassen sich mit Hilfe ihres Rangefälles abschätzen, das aus den Eisgrenzen, aus gleichzeitigen Rückzugsmoränen oder seitlichen Schmelzwasserrinnen hergeleitet werden kann, wobei sowohl das seitlich wie noch vorne zu den Rändern gerichtete Gefälle zu berücksichtigen ist. Die Profile können durch eine Parabel mit der Gleichung

$$
h=A x^{t}
$$

angenähert werden, in $\operatorname{der} h$ die Höhe über dem Gletscherende und $x$ die Entfernung davon sind, während der Koeffizient $A$ von Gletscher zu Gletscher wechselt. Der Koeffizient $A$ hat einen Wert von $4,7 \mathrm{~m}^{1}$ sowohl für das antarktische Inlandeis bei Mirny wie für das Inlandeis an der mittleren Westküste von Grönland. Mehrere Eis-Loben des späten Pleistozän in gebirgigen Gegenden von Nordamerika und Neusseeland haben A-Werte von $2,9 \mathrm{~m}^{\dagger}$ bis etwa $4,1 \mathrm{~m}^{\dagger}$. Bei mehreren Eis-Loben im südwestlichen Teil des spät-pleistozänen Laurentidischen Eisschildes liegen jedoch die Werte zwischen etwa 0,3 und $1,0 \mathrm{~m}^{\mathbf{t}}$, was einer Scherspannung am Grund von ungefähr 0,07 bis 0,22 bar entspricht. Eine grösseres Problem besteht hier darin, die aktive Bewegung des Eises bei solch niedrigen Oberflächengradienten und Scherspannungen zu erklären. Im Gelände sollte nach Anzeichen von Gleiten am Untergrund, das durch hohen subglazialen Wasserdruck ermöglicht worden sein könnte, gesucht werden. Aber auch andere Möglichkeiten für die Erklärung solch niedriger Oberflächengradienten sollten erwogen werden.

\section{INTRODUCTION}

Profiles of late Pleistocene glaciers can be estimated in many places from the elevations of moraines and the upper limits of erratics on valley walls and nunataks at varying distances from the former termini. Such studies have, for example, been made in northern Washington 
state (Flint, r937) in British Columbia (Anon., r956; Falconer and others, 1958), in Yukon Territory (Rampton, 1969) and in the New Zealand Alps (Mathews, 1965). In relating marginal to axial profiles allowance should be made for the convexity of a glacier tongue that typically occurs below the firn line (Mathews, 1965, p. 150). The observations hitherto made in these mountain areas indicate axial profiles (Fig. I) fitting approximately the parabolic formula:

$$
h=A x^{\frac{1}{2}}
$$

in which $h$ is the elevation of the ice surface above its terminus, $x$ is the distance up-stream from its terminus in the same units, and $A$ is a coefficient which varies from glacier to glacier. The coefficient $A$ proves in these cases to have values close to $3.0 \mathrm{~m}^{\frac{1}{2}}$.

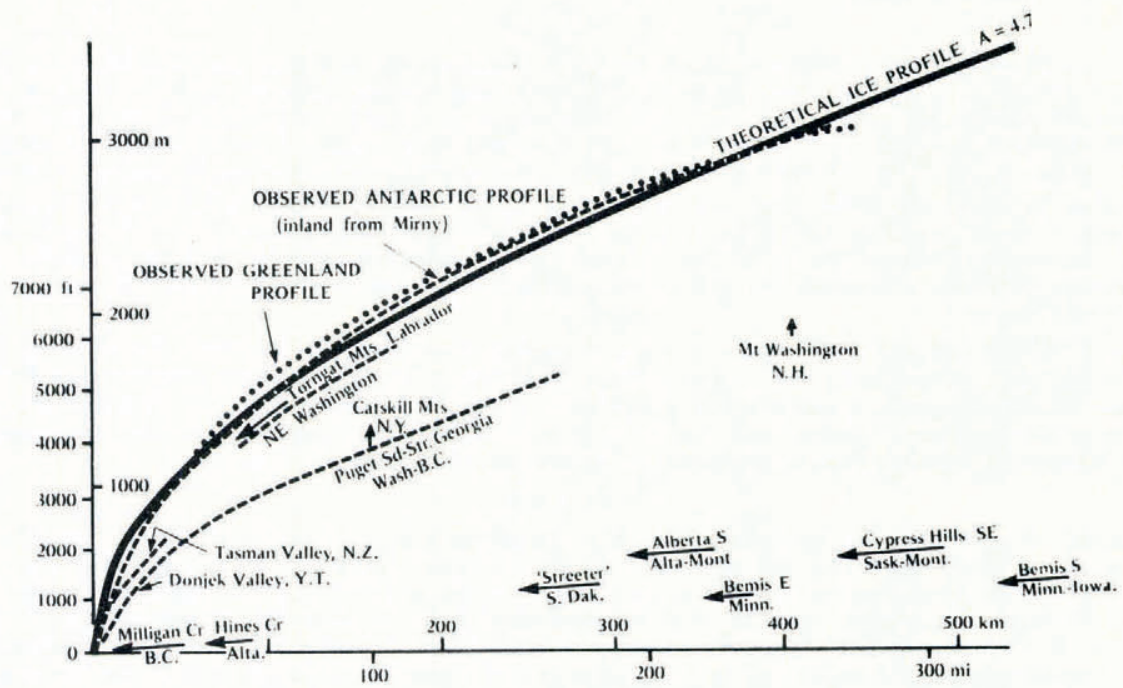

Fig. I. Height of present or former ice surfaces at various distances up-stream from the termini. Vertical arrows indicate mountain tops overridden by ice.

Hollin ( 1962 ) using this formula with a value of $A=4.7 \mathrm{~m}^{\frac{1}{2}}$ finds that it fits very well to the profile of the present Antarctic ice sheet for the first $375 \mathrm{~km}$ inland from Mirny (Fig. I). In this case the basal shear stress on a horizontal substratum with an elevation of that of the terminus is very close to I bar, the figure used by Nye (1952) as a convenient round number for alpine glaciers. For Greenland between Jakobshavn Isfjord, where there is a break in the partly buried mountain chain ringing the interior basin, and Ismitte, a value of $A=4.7 \mathrm{~m}^{\frac{1}{2}}$ is also appropriate.

More sophisticated formulae are available than the one offered here to express the profile of an ice tongue or ice sheet, taking into account, for example, the general slope of the substratum, the cross-sectional shape of the valley floor, the net rate of accumulation, and the rounded form of the ice divide. For the purposes of this paper, however, these are less useful than the parabolic formula in that the examples of prime interest here occur where the substratum has in general a low slope, valleys are all broad, net annual accumulation in Pleistocene is not known, and the sites are far removed from the ice divide. The parabolic formula, moreover, readily provides a unique coefficient given only two points attained simultaneously on a former ice surface. The coefficient and formula, even if they fail to offer a perfect fit, do make it possible to compare the profiles of different ice tongues for which only limited data are available. 


\section{DATA From the LAURentide AREA}

The late Pleistocene Laurentide ice sheet, which covered nearly all of Canada east of the Rocky Mountains and extended into the northern United States, presents major problems in the reconstruction of its surface form. Over much of its extent it moved across or into areas of limited topographic relief. On the east it crossed high ground but buried this completely or nearly so, and terminated beyond the present coast. In only a few places has it left terminal or recessional features which have been traced, or identified as contemporaneous, through any substantial vertical range. The data, moreover, are generally sufficient only to obtain surface elevations at a few points at measurable distances upstream from what is believed to be the contemporaneous ice limit. A parabolic profile has been assumed for these cases as a basis for comparison with data from other localities. The value of $A$ necessary to fit the parabola simultaneously through the data points and the ice limit proves to be remarkably low in a number of areas which, accordingly, merit special comment.

One area with a small value of $A$ straddles the United States-Canada boundary, east of the Rocky Mountain front (Fig. 2). Here an extreme outer limit to the Laurentide ice has been mapped in Montana (Alden, I932; Colton and others, I96I) and an extreme upper limit has been reported in the Rocky Mountain foothills and on several nunataks to the east (Stalker, 1965; Horberg, 1954; Lemke and others, 1965). Contours on the surface have been inferred by the present author on the assumptions: ( $\mathrm{I}$ ) that all limits are contemporaneous; (2) that the curvature indicated by the bowing of the ice limits into broad valleys represents the convexity of the ice lobe at lower elevations; (3) that this convexity diminishes upstream to zero in central Alberta ; and (4) that abrupt changes in strike of the ice surface are concentrated over buried ridges. Should the upper limits on the nunataks prove to represent a different ice advance than that which formed the outer limits in the lowlands to the south, two profiles must have existed, one steeper, the other less steep than the one indicated here. Gradients (Fig. I) have been measured perpendicular to the strike of the contours so as to parallel the inferred flow directions. One such profile happily parallels the observed trend of

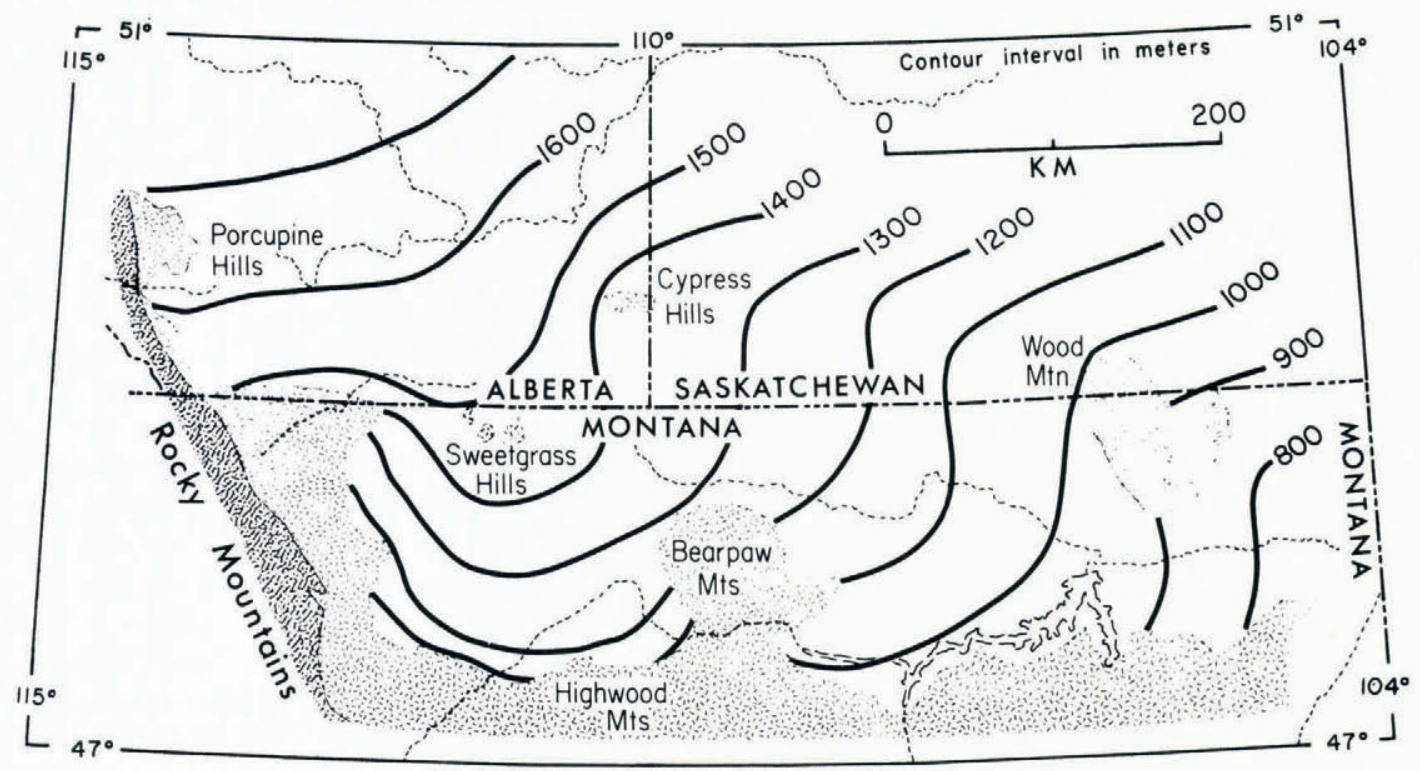

Fig. 2. Inferred upper limit of the south-western part of the Laurentide ice sheet indicated by contours at Ioo $m$ intervals. Unglaciated areas stippled. 
striae and a train of erratics in Montana (Colton and others, I96r). Two profiles so determined have values of $A$ equalling $\mathrm{I} .0 \mathrm{~m}^{\frac{1}{1}}$ and $0.67 \mathrm{~m}^{\frac{1}{3}}$ (Fig. I).

Additional examples of low profiles can be drawn from the positions, and elevations, of recessional moraines in (I) the James River valley of South Dakota and (2) the Minnesota and Des Moines valley of Minnesota and Iowa. Here the Laurentide ice moved southward in tongues 300 to almost $500 \mathrm{~km}$ long but barely $100 \mathrm{~km}$ wide, carrying erratics from the Canadian shield and producing nearly continuous morainal ridges, on the floors and slopes of the broad valleys. Relief of the terrain is scarcely $300 \mathrm{~m}$ but topographic control of the shape of the tongues is still obvious. From the mapped positions of the moraines (Flint and others, r959) and their elevations as obtained from topographic maps it is easy to obtain marginal profiles. In reconstructing axial profiles it has been assumed that from a point on the axis at the base of each tongue the same parabolic profile (i.e. the same value of $A$ ) applies for the side slopes to the two lateral margins as for the forward slope to the down-stream terminus. This assumption almost certainly yields a high value for the elevation of the point at the upstream end of the profile and thus errs on the high side in arriving at a value for $A$. For the South Dakota ice tongue responsible for the "Streeter" moraine (so named in North Dakota), a drop from no more than $775 \mathrm{~m}$ a.s.l. (2 $55^{\circ} \mathrm{ft}$ ) at latitude $45^{\circ} 30^{\prime} \mathrm{N}$. to $400 \mathrm{~m}$ ( $1300 \mathrm{ft}$ ) at lat. $43^{\circ} \mathrm{O}^{\prime}$ is indicated, corresponding to a value of $A=0.73 \mathrm{~m}^{\frac{1}{2}}$. For the ice tongue farther east which was responsible for the Bemis moraine a drop along the axis from an altitude of no more than $640 \mathrm{~m}$ a.s.l. (2 $100 \mathrm{ft}$ ) near the north-east corner of South Dakota to $300 \mathrm{~m}$ ( $975 \mathrm{ft}$ ) at Des Moines, Iowa, $55^{\circ} \mathrm{km}$ to the south-east, is indicated. An easterly branch of this same ice tongue falls to an altitude of $305 \mathrm{~m} \mathrm{(} \mathrm{I}$ ooo ft) at a point $80 \mathrm{~km}$ north-east of Minneapolis, Minnesota, and $370 \mathrm{~km}$ from the north-east corner of South Dakota. The southern and eastern branches of this ice tongue yield values for $A$ of $0.46 \mathrm{~m}^{\frac{1}{2}}$ and $0.55 \mathrm{~m}^{\frac{1}{2}}$ respectively.

Evidence of a different kind can be found in the Peace River valley of north-western Alberta between lat. $5^{\circ}$ and $5^{8^{\circ}} \mathrm{N}$. Here the Laurentide ice at the time of its last active movement flowed southward up the valley, engraving on the ground surface a pattern of grooves diverging southward, apparently moving toward a convex ice front. Southward draining marginal melt-water channels high on the flanks of the broad valley were formed at about this stage. On the west side one such melt-water chain can be traced almost continuously from an altitude of $75^{\circ} \mathrm{m}\left(245^{\circ} \mathrm{ft}\right)$ at lat. $57^{\circ} \mathrm{IO} \mathrm{O}^{\prime} \mathrm{N}$. southward across at least one ice-dammed lake basin, to a delta at $650 \mathrm{~m}(2150 \mathrm{ft})$ near the town of Hines Creek, a drop of $100 \mathrm{~m}$ in $100 \mathrm{~km}$. The ice-dammed lake into which this delta formed seems to have had its outlet either $60 \mathrm{~km}$ to the south or $90 \mathrm{~km}$ to the south-east, at the axis of the ice lobe. A possible up-stream continuation of this chain can be traced almost to the crest of the Naylor Hills (lat. $56^{\circ} 30^{\prime} \mathrm{N}$.) at an elevation of $760 \mathrm{~m}(2500 \mathrm{ft})$. Although the channel system is not a strictly lateral one, an ice withdrawal of only $15 \mathrm{~km}$ anywhere along its length would have led to its abandonment. Even allowing for the convexity of the Peace River ice lobe, a fall of only about $100 \mathrm{~m}$ in the lowermost $100 \mathrm{~km}$ of its axis is indicated, corresponding to values of $A$ equal to $0.32 \mathrm{~m}^{\frac{1}{2}}$. Another much shorter melt-water system at the upper part of Milligan Creek, $120 \mathrm{~km}$ to the north-west of Hines Creek, yields similar low values (Fig. I).

Lest the impression be given that the Laurentide ice sheet was characterized throughout its former extent by very low surface profiles, three other examples with appreciably steeper slopes may be cited.

(I) Cap Mountain (altitude I 560 m or 5 I $25 \mathrm{ft}$ ) east of Mackenzie River at lat. $63^{\circ} 25^{\prime} \mathrm{N}$. bears clear striae on its summit (Williams, 1923) and has been overriden by Laurentide ice, apparently in Wisconsin time. The summit lies $730 \mathrm{~km}$ up-stream from the Wisconsin ice limit near the mouth of Mackenzie River. A minimum value of $A$ of $1.8 \mathrm{~m}^{\frac{1}{2}}$, and an average basal shear stress on the lowland between the two points of about $0.4 \mathrm{bar}$, is indicated.

(2) Mount Washington, New Hampshire (altitude I $920 \mathrm{~m}$ or $6288 \mathrm{ft}$ ) lies about $400 \mathrm{~km}$ up-stream from the submerged terminal moraine of the ice sheet in the Gulf of Maine. The 
ice which overrode this summit (Goldthwait, I940) would have had to have a profile which if parabolic would require $A$ to be not less than $3.0 \mathrm{~m}^{\frac{1}{2}}$.

(3) The coastal mountains of northern Labrador (lat. $57^{\circ} 55^{\prime} \mathrm{N}$.) bear erratics to at least I $190 \mathrm{~m}(3900 \mathrm{ft})$ and the higher Torngat Mountains (lat. $59^{\circ} \mathrm{IO}^{\prime} \mathrm{N}$.) bear erratics of Wisconsin (Ives, I957) or earlier (?) age (Ives, I963) to I $550 \mathrm{~m} \mathrm{(5} 100 \mathrm{ft}$ ) above sea-level. The edge of the continental shelf at $-200 \mathrm{~m}$, the probable outermost limit of the ice sheet, lies I I 5 and $160 \mathrm{~km}$ respectively east of the two points in question. To have simultaneously reached these altitudes and the shelf edge, an ice cap with a parabolic profile having $A=4 . \mathrm{I}^{\frac{1}{2}}$ would be required.

Still other examples may perhaps be available in the literature; others will undoubtedly be found during further exploration, especially in northern and eastern Canada. Local knowledge will, however, be needed to confirm the contemporaniety of ice-marginal features over a sizeable area and through an appreciable range of altitudes before reliable values of $A$ can be obtained.

In the reconstruction of the former profiles of the ice sheet the effects of isostatic tiiting have been ignored, in part because precise data are not available from the areas in question. Since, however, postglacial uplift in the inner parts of the ice cap have been greater than in the marginal regions (Andrews and Barnett, 1972; Walcott, 1972) the profiles as reconstructed today can be expected to be somewhat higher than they actually were in the past. Profiles that appear abnormally low now would have been still lower when formed.

\section{Discussion}

A cause, or causes, of the highly variable, and particularly of the abnormally low, profiles should be sought.

Of the examples cited those with values of $A \geqslant 2.9 \mathrm{~m}^{\frac{1}{2}}$ are all for ice lobes traversing mountainous terrain and those with values of $A \leqslant \mathrm{r} .0 \mathrm{~m}^{\frac{1}{2}}$ occur in the south-western sector of the Laurentide ice sheet where the ice was occupying very broad valleys or crossing plateaus in areas where total relief was $600 \mathrm{~m}$ or less. Configuration of the terrain thus seems to play a part.

Overall slope of the terrain does not, on the other hand, appear to have played a significant role in favouring low surface slopes to the ice lobes. Thus the ice lobe near Hines Creek moved up-valley, but at Milligan Creek and in the Minnesota-Iowa area they moved down rather gently sloping valleys. The South Dakota lobe crossed what was at the time a divide and moved onto a very slight downgrade. Ice in southern Alberta and adjacent Montana and Saskatchewan was, in general, moving across the general slope.

For those ice lobes with very low surface profiles and moving over nearly horizontal ground along very broad valleys, the basal shear stress can be computed as being a small fraction (about 7 to $21 \%$ ) of the 1 .o bar considered normal for active ice tongues (Nye, 1952). Ice flow resulting from internal deformation would appear to have been exceptionally sluggish; indeed, it might be questioned how ice with such low basal shear stress could move forward and build morainal ridges containing far-travelled erratics. Basal slip may provide an answer to this dilemma, but if such basal slip did occur we would have to infer the presence of water under fairly high pressure either as a film at the base of the ice (Weertman, 1964; Paterson, 1969) or within the pores of the underlying sediment at or close to the ice-sediment contact (Mathews and Mackay, 1960). This in turn implies that the temperature in the basal ice should have been at or close to the pressure melting point.

Little is known to date on basal ice temperatures in modern ice sheets. Observations at "Byrd" station in Antarctica (Gow and others, 1968) shows the presence of free water at the base of the ice sheet whereas drilling at Camp Century, Greenland (Hansen and Langway, 1966) indicates that the base of the ice cap is many degrees below the pressure melting point. 
Zotikov ( 1963 ) suggested on theoretical grounds that the base of the Antarctic ice sheet below the Mirny profile is well below the pressure melting point over much of its length. Here the ice may, therefore, be frozen to its bed and its movement accordingly would be a product wholly of internal deformation, hence, perhaps, the reason for the relatively high profile. Low temperature within the ice may, moreover, render the ice more difficult to deform and hence encourage high profiles.

If the abnormally low profiles which exist in the south-western part of the Laurentide ice sheet are a response to basal sliding aided by high subglacial water pressure, some characteristics should be looked for in or on, the sediments overriden by this ice:

I. Abnormally low degree of preconsolidation considering the depth of ice which had overriden these sediments.

2. A record of very active overriding by ice, perhaps unusually effective smoothing or fluting of the terrain and strong orientation of fabric within the uppermost sediments.

3. Any evidence of permafrost in the sediments at the time of ice advance should be accompanied by ice thrusting of these sediments; conversely in the absence of ice thrusting, signs of contemporaneous permafrost should be lacking.

The problem is by no means resolved. Though the evidence of abnormally low surface profiles is clear in the south-western part of the Laurentide ice sheet, the mechanics of flow remains in question. More field evidence should be sought in these localities; further thought should be given for alternative proposals for the mode of movement.

\section{ACKNOWLEDGEMENTS}

Library facilities of the Geological Survey of Canada, Ottawa, and financial support from the National Research Council of Canada aided in the preparation of this report. Thanks are also owing to Drs J. R. Mackay and W. S. B. Paterson for critical reviews of the manuscript.

MS. received 27 June 1973

\section{REFERENCES}

Alden, W. C. 1932. Physiographic and glacial geology of eastern Montana and adjacent areas. U.S. Geological Survey. Professional Paper 174.

Andrews, J. T., and Barnett, D. M. 1972. Analysis of strandline tilt directions in relation to ice centers and postglacial crustal deformation, Laurentide ice sheet. Geografiska Annaler, Vol. 54A, No. 1, p. I-1 1.

Anon. 1956. Glacial geology. (In Chapman, J. D., and Turner, D. B., ed. Atlas of resources of British Columbia. Victoria, B.C., British Columbia Natural Resources Conference, map 4.)

Colton, R. B., and others. $196 \mathrm{I}$. Glacial map of Montana east of the Rocky Mountains, by R. B. Colton, R. W: Lemke and R. M. Lindvali. U.S. Geological Survey. Miscellaneous Geological Investigations, Map I-327.

Falconer, G., and others. 1958. Glacial map of Canada, by G. Falconer, W. H. Mathews, V. K. Prest and J. T. Wilson. 'Toronto, Geological Association of Canada.

Flint, R. F. 1937. Pleistocene drift border of eastern Washington. Bulletin of the Geological Society of America, Vol 48, No. 2, p. 203-31.

Flint, R. F., and others. I959. Glacial map of the United States east of the Rocky Mountains, by R. F. Flint, R. B. Collon, R.P. Goldthwait and H. B. Willman. Boulder, Colorado, Geological Society of America.

Goldthwait, R. P. 1940. Geology of the Presidential Range. Bulletin of the New Hampshire Academy of Sciences, $\mathrm{I}$,

p. 1-44.
Gow, A. J. and others. 1968. Antarctic ice sheet preliminary results of first core hole to bedrock, by A. J. Gow, H. T. Veda and D. E. Garfield. Science, Vol. 161, No. 3845 , p. I01 1-13.

Hansen, B. L., and Langway, C. C., jr. I 966 . Deep core drilling in ice and core analysis at Camp Century, Greenland, I961-1966. Antarctic Fournal of the United States, Vol. 1, No. 5, p. $207-08$.

Hollin, J. T. I962. On the glacial history of Antarctica. Journal of Glaciology, Vol. 4, No. 32, p. $173-95$.

Horberg, L. 1954. Rocky Mountain and Continental Pleistocene deposits in the Waterton region, Alberta, Canada. Bulletin of the Geological Society of America, Vol. 65, No. 1 I, p. 1093-1 150.

Ives, J. D. 1957. Glaciation of the Torngat Mountains, northern Labrador. Arctic, Vol. 10, No. 2, p. 67-68.

Ives, J. D. 1963. Field problems in determining the maximum extent of Pleistocene glaciation along the eastern Canadian seaboard-a geographer's point of view. (In Löve, Á., and Löve, D., ed. North Atlantic biota and their history. Oxford, Pergamon Press, p. 337-54.) 
Lemke, R. W., and others. 1965. Quaternary geology of northern Great Plains, by R. W. Lemke, W. M. Laird, M. J. Tipton and R. M. Lindvall. (In Wright, H. E., jr., and Frey, D. G., ed. The Quaternary of the United States. Princeton, N.J., Princeton University Press, p. I5-28.)

Mathews, W. H. 1967. Profiles of late Pleistocene glaciers in New Zealand. New Zealand Journal of Geology and Geophysics, Vol. 10, No. I, p. 146-63.

Mathews, W. H., and Mackay, J. R. 1960. Deformation of soils by glacier ice and the influence of pore pressures and permafrost. Transactions of the Royal Society of Canada, Ser. 3, Vol. 54, Sect. 4, p. 27-36.

Nye, J. F. 1952. A method of calculating the thicknesses of the ice-sheets. Nature, Vol. I69, No. 4300, p. 529-30.

Paterson, W. S. B. ${ }^{1} 969$. The physics of glaciers. Oxford, Pergamon Press. (The Commonwealth and International Library. Physics Division.)

Prest, V. K., and others. 1968. Glacial map of Canada, by V. K. Prest, D. R. Grant and V. N. Rampton. Canada. Geological Survey, Map i253A.

Rampton, V. N. Unpublished. Pleistocene geology of the Snag-Dlutlan area, southwestern Yukon Territory, Canada. [Ph.D. thesis, University of Minnesota, 1969.]

Stalker, A M. 1965. Pleistocene ice surface, Cypress Hills area. (In Zell, R. L., ed. 15th annual field conference guidebook, Cypress Hills plateau. Calgary, Alberta Society of Petroleum Geologists, p. I $16-30$.

Walcott, R. I. 1972. Late Quaternary vertical movements in eastern North America: quantitative evidence of glacio-isostatic rebound. Reviews of Geophysics and Space Physics, Vol. 10, No. 4, p. 849-84.

Weertman, J. I964. The theory of glacier sliding. Journal of Glaciology, Vol. 5, No. 39, p. 287-303.

Wheeler, E P., II. 1958. Pleistocene glaciation in northern Labrador. Bulletin of the Geological Society of America, Vol. 69, No. 3, p. $343-44$.

Williams, M. Y. I923. Reconnaissance across northeastern British Columbia and the geology of the northern extension of Franklin Mountains, Northwest Territories. Canada. Geological Survey. Summary Report, 1922, p. $65^{\mathrm{B}-87 \mathrm{~B}}$

Zotikov, I. A. 1963. Bottom melting in the central zone of the ice shield on the Antarctic continent and its influence upon the present balance of the ice mass. Bulletin de l'Association Internationale d'Hydrologie Scientifique, 8 e An., No. I, p. 36-44. 